\section{Oppe Orsolya}

\section{A Dél-tiroli német kisebbség törekvései}

Olaszországban az etnikai és regionális megosztottságoknak mély gyökerei vannak. A már meglévő klasszikus regionális különbségeket és az újonnan keletkező politikai-gazdasági törésvonalak okozta aránytalanságokat eddig nem sikerült kiegyenlíteni az olasz kormány(ok)nak. Tanulmányom célja, hogy bemutassam, milyen kihívást jelent a mindenkori olasz kormány számára a Dél-Tirolban élő német ajkú kisebbség politikai, gazdasági és társadalmi törekvéseinek kezelése. A három tényezőt nehezen lehet szétválasztani, hiszen a régió történelmi gyökerei, az ott élö német kisebbség közel egy évszázados politikai küzdelme, az Olaszországot kezdetektől „kettéválasztó” Észak-Dél törésvonal a mai napig meghatározza az ország és a térség arculatát. Ezekhez a már meglévő ellentétekhez az elmúlt esztendőkben újabb konfliktusok társultak, elsősorban gazdasági és politikai jellegüek, melyekre az alábbi tanulmányban szeretnénk részletesen kitérni.

Vajon az olasz egység által megteremtett olasz nemzet mennyire tekinthető egységesnek és mit jelent „olasznak” lenni egy olyan államban, ahol számos nyelvi kisebbség él? Nem beszélve arról, hogy a történelmi etnikumok mellett ma migránsok tömegei érkeznek a félszigetre magukkal hozva sajátos kultúrájukat. Az etnikai és regionális alapon szerveződő pártok jelenléte a mai olasz politikai köztudatban sok esetben egyet jelent a regionális identitás elfogadásával, illetve a nemzeti identitás tagadásával.

\section{Megvalósul az egységes olasz állam}

A jelenség megértéséhez egészen az olasz egységfolyamat kezdeti időszakáig kell visszanyúlni. A 19. század nemzeti forradalmai elérték az Itáliai-félszigetet is. A nacionalizmus megerősödése a széttagolt Itáliaifélszigeten ${ }^{1}$ is egységesítő törekvéseket hozott felszínre. 1848-49-ben a

\footnotetext{
${ }^{1}$ Az osztrák császársághoz tartozott a Lombard-Velence Királyság, emellett osztrák befolyás alá tartoztak a közép-itáliai kis fejedelemségek, továbbá Itália a Pápai Államra (Vatikán) és a Nápolyi és Szicíliai Királyságra tagolódott.
}

nemzeti kérdés ügyét legaktívabban a Szárd Királyság támogatta. Azonban önmagában a szárd állam képtelen lett volna megteremteni az egységes olasz államot. Az olasz egység megvalósításának ügyét Camillo Cavour, Piemont miniszterelnöke karolta fel, aki dinasztikus úton, külső támogatással képzelte el a félsziget egységesítését. Ennek legnagyobb akadálya Ausztria volt, vele szemben Cavournak nagyhatalmi szövetségest kellett találnia. Piemont ezért részt vett a krími háborúban (1853-1856), ahol 1859-ben sikerült osztrákellenes szövetséget kötnie III. Napóleonnal. Cavour és III. Napóleon megállapodása szerint Ausztria legyőzése után észak-olasz királyság alakult volna Viktor Emánuel vezetésével, Közép-és Dél-Itália francia befolyás alá került volna, míg a szárd királyság átengedte volna Franciaországnak Savoyát és Nizzát. Camillo Cavour francia támogatással legyőzte Ausztriát a híres solferinói csatában (1859), de az ütközet után III. Napóleon váratlanul különbékét kötött Ausztriával Villafrancában, így Piemont csak Lombardiát tudta megszerezni. Ezt a lépést az a tény magyarázhatja, hogy III. Napóleon nem akart egy erős, egységes olasz államot Franciaország szomszédságában, márpedig Ausztria teljes veresége szerinte ehhez vezetett volna (Ormos-Majoros 1998: 94-97.)

A félszigeten a nemzeti-liberális felkelések sorra gyengítették az osztrákok uralmát. Az egyesítést Garibaldi folytatta, aki sikerrel döntötte meg a Bourbon-uralmat a nápolyi királyságban. 1860 októberében népszavazással Nápoly és Szicília is csatlakozott Piemonthoz. 1861. március 18-án kikiáltották az olasz királyságot, amely immár egész Itáliát egységesítette Róma és Velence kivételével. A főváros átmenetileg Firenze lett.

Az egységfolyamat további sikeréhez Ausztria külpolitikai kudarca járult hozzá. A poroszoktól elszenvedett vereség fejében az osztrákoknak le kellett mondaniuk az olaszok javára Velencéről, míg az 1870-es poroszfrancia háború eredményeképpen a franciáknak el kellett hagyniuk a pápai államot, melyet szintén Olaszország szerezhetett meg.

\section{Etnikai, regionális ellentétek}

Olaszország másfél százados történelmében számos olyan neuralgikus pontot és eseményt találunk, amelyek megkérdőjelezik az egységes 
nemzetállam létét. Melyek lehetnek ezek? Történelmi események, békeszerződések határozatai, nemzeti-etnikai konfliktusok, gazdasági ellentétek és ezekből fakadóan eltérő regionális sajátosságok. Olaszország már régóta nemcsak a fejlett Észak és a gazdaságilag elmaradt Dél (Mezzogiorno) dichotómiájával írható le, hanem számos más ellentmondás is jellemzi.

Területi igényeket tekintve az új állam már 1870-ben megszületett, de kevésbé tudatosult az átlag állampolgárban, hogy mit jelent a valóságban „olasznak lenni”, és miben áll az olasz nemzeti identitás. A Risorgimento ${ }^{2}$ révén a félsziget egységessé vált a 19. század végére, de maradtak olyan területek, ahol vegyes nemzetiségü (német, olasz, ladin, szlovén, horvát, francia, albán stb.) lakosság élt. pl: az Aosta-völgyben élő frankoprovanszál népcsoport, a Friuli-Venezia Giuliában élő szlovén kisebbség, a Dél-Tirolban élő német ajkú lakosság és Itália déli részen, Apulia, Szicília térségében élő görögök és albánok (Sipos 1993: 54-66.).

A rövid történelmi áttekintés után érdemes egy pillantást vetni a 21 . század Olaszországára. Olaszország nem rég ünnepelte a félsziget egységének 150. évfordulóját. Azonban a nemzeti összetartozás eszméjét hirdető rendezvénysorozat nem minden esetben talált kedvező fogadtatásra a politikusok, pártok, közéleti szereplők, társadalmi mozgalmak körében.

Míg Berlusconi és pártja, a Szabadság Népe és a Balközép Demokrata Párt az évfordulót méltatta, addig az Északi Liga, Umberto Bossi vezetésével $^{3}$ a központi rendelettel szemben nem tekintette munkaszüneti napnak az évfordulót. A megemlékezéseken az olasz himnusz helyett a Nabuccóból énekelték a Rabok Kórusát (Sachelli, 2011).

Az ünnepségektől távol maradt több regionális mozgalom, szervezet és azok vezetői is. A megemlékezésen nem vett részt a dél-tiroli régió elnöke, Luis Durnwalder és pártja, a Dél-Tiroli Néppárt (SVP) sem. Az olasz egység emlékére szervezett évforduló így még inkább felszínre

\footnotetext{
${ }^{2}$ Olasz egységfolyamat elnevezése.

${ }^{3}$ Umberto Bossi jobboldali politikus pártja, a Lega Nord 1989-ben alakult. 1994-re a jobboldalon, több párttal együtt (Forza Italia, Polo della Libertá) tagja lett az első Berlusconi-kormánynak. A kezdetben kimondottan radikális és szakadár nézeteket valló Bossi Padania függetlenségéért és elszakadásáért küzdött, mára enyhített korábbi propagandáján, és jelenleg a föderatív átalakítás mellett érvel Olaszországban.
}

hozta az olasz nemzeti identitás problematikáját, vagy bizonyos esetekben pontosan annak hiányát.

Tanulmányomban egy olyan térség, régió bemutatására vállalkozom, ahol az eddig leírt és megfogalmazott etnikai, regionális ellentétek és az olasz identitásválság jelenségei együttesen jelennek meg. Ezért esett választásom Dél-Tirolra, amely önmagában egy sajátosnak mondható önrendelkezési modellt hozott létre.

\section{Dél-Tirol története, helyzete és jogállása}

A 20. század elejéig Tirol egységes volt, és Ausztriához tartozott. Az első világháború után (1919) a területet felosztották, aminek következtében Tirol déli része Olaszországhoz került.

1. ábra

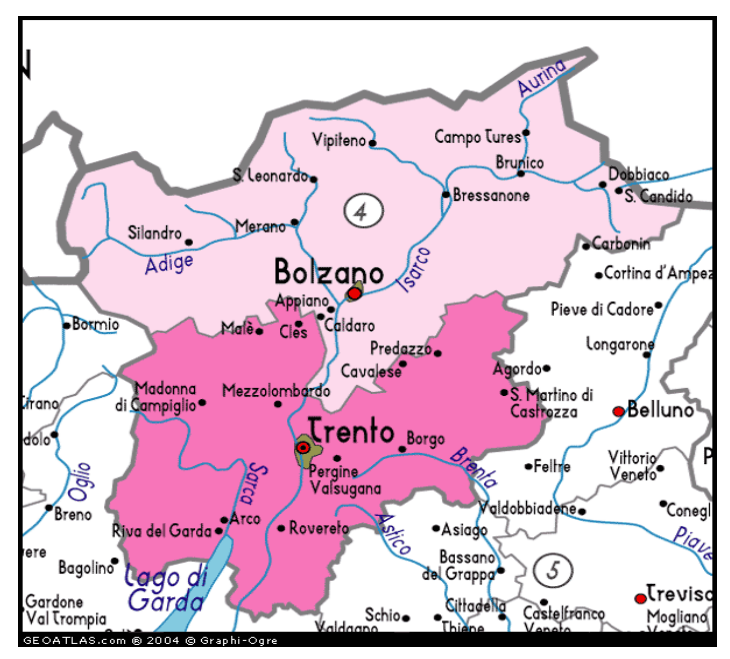

forrás: www.geoatlas.com

Dél-Tirol története és autonómiamodellje sokak számára példaértékü Európában, bár a modell megteremtéséhez vezető utat több évtizedes politikai csatározások, konfliktusok és diplomáciai egyeztetések előzték meg. Olaszországban öt terület rendelkezik alkotmány által biztosított autonóm státusszal: Dél-Tirol (Trentino-Alto Adige), Szicília, Szardínia, 
Friuli-Venezia Giulia, Valle d'Aosta. Kijelölésüket az olasz kormány a kulturális sajátosságok, nemzeti hagyományaik figyelembevételével tette meg (Nagy 2009: 28-35.).

Az autonómia értelmezésében Miklósné Zakar Andrea megfogalmazását választottam, mely szerint „,autonómiának tekinthető egy adott közösségnek valamilyen érdekképviseleti vagy akár bizonyos igazgatási jogosítványokkal bíró intézményrendszerrel való felruházása, mely jogosítványok kötődhetnek a közösség által lakott terület egészéhez, esetleg egy részéhez, de átfogja a közösséghez tartozó vagy oda tartozni akaró (identitást felvállaló) összes individuumot" (Miklósné 2010: 75-91.).

Dél-Tirol esetében az események egészen az első világháborúig nyúlnak vissza. A világháborút lezáró, Saint-Germainben aláírt békeszerződés nyomán a mintegy 97\%-ban németek lakta Dél-Tirolt Olaszországhoz csatolták. A múlt század elején Bolzano térségében 215 ezer német, 16 ezer olasz és pár ezer ladin ${ }^{4}$ élt. Az olasz politika célja a kezdetektől fogva a német ajkú lakosság asszimilációja volt, hogy a térségben az olaszok javára változtassák meg az etnikai arányokat. Az 1920-as évektől a fasizmus megerősödésével Mussolininek feltett szándéka volt, hogy az ország területén élő nemzeti kisebbségeket asszimilálja. Az erőszakos olaszosítás eredményeképpen jelentősen megnőtt az olasz lakosok aránya a térségben, miközben a német ajkúak nagy számban hagyták el a régiót.

A második világháború után a terület kérdésének rendezésére a párizsi külügyminiszteri konferencián az osztrák és olasz fél között kétoldalú tárgyalások kezdődtek. Az 1946. szeptember 5-én Párizsban aláírt Gruber-De Gasperi egyezmény teljes jogegyenlőséget biztosított Bozen/Bolzano és Trient/Trento kétnyelvü településein élő német anyanyelvü lakosságnak. Ez a lépés azért volt kulcsfontosságú, mert megteremtette a dél-tiroli autonómia alapját, és a régió kérdése már nem kizárólag olasz belügy volt. Ez a kétoldalú megállapodás az 1947. évi olasz békeszerződés 4 . sz. mellékleteként szerepel, és a szerződés fontos részét képezi. 1947-ben tehát megszületett a terület első autonómiastatútuma, de az olasz kormány továbbra sem törődött bele a dél-tiroli autonómia ügyébe, így 1948-ban ellenlépéseket tett. Az 1948. január 30-

\footnotetext{
${ }^{4}$ A ladinok a római birodalom idején latinizálódtak, nyelvi rokonságban vannak a svájci
} réto-románokkal, valamint a katalánokkal án elfogadott 5. sz. alkotmánytörvény jóváhagyta Trentino-Alto Adige különleges jogállású régió statútumát. Ez azt jelentette, hogy a német többségü Bolzano tartományhoz hozzákapcsolták az olasz többségü Trentinót, így végül a német ajkúak kisebbségbe kerültek a térségben (Schönbaum 2008: 7-26.).

A kialakult helyzetbe sem az 1945-ben megalakult Dél-Tiroli Néppárt (Südtiroler Volkspartei, SVP), sem Ausztria nem nyugodott bele, és többször is az ENSZ közgyüléséhez fordult a kérdés békés rendezése érdekében. Igénye jogos volt, hiszen 1961-re a lakosságnak már csak 66\%-a volt német ajkú. Olaszország továbbra sem módosította az első autonómia-statútumot, ezért Ausztria kezdeményezésére az ENSZ 1961. november 28-ai közgyülése ismét felhívta a feleket a konfliktus rendezésére. Az olasz kormány létrehozta az ún. „Tizenkilencek Bizottságát”, amelyben 11 olasz, 7 német és 1 ladin tag vett részt. A testület három év alatt dolgozta ki javaslatait, amely az ún. dél-tiroli javaslatcsomagként (Paket) vált ismertté. A dél-tiroli csomag 137 intézkedést tartalmazott, melyet 1971-ben alkotmánytörvénnyel is megerösítettek. Így az 1972-ben életbe lépett második statútum különleges autonómiát biztosított a térségnek, de a dél-tiroli kérdés végleges lezárására a két fél között csak 1992. június 19-én került sor (Szomráky-Rajnavölgyi 1999: 7-11.).

A Dél-Tirolra érvényes autonómiamodell a következőképpen rendelkezik kisebbségi kérdésekben:

- Dél-Tirol a saját és a régiót érintő kérdésekben jogszabályok kidolgozására jogosult törvényhozó és végrehajtó hatalmi szervvel rendelkezik. Törvényhozó testülete a Régiótanács lett, amely 70 főből áll. A végrehajtó hatalmat a Régióbizottság testesíti meg, melyet az elnök, két alelnök, valamint két tényleges és két helyettes ülnök alkot.

- A tartomány teljes autonómiát élvez az oktatás, ipar, turizmus, kereskedelem, környezetvédelem és a településfejlesztés terén.

- Nem rendelkezik hatáskörrel a katonaság, rendőrség, biztonsági szolgálat, bíróság, adók, vámok terén.

- A pénzügyek tekintetében a tartománynak nincs önálló adóztatási joga. 
- Az etnikai hovatartozás az alábbi speciális terülteken jelenik meg: anyanyelvű oktatás esetén az óvodákban, iskolákban, emellett a köztisztviselöi és közalkalmazotti helyek betöltésekor, illetve a bírósági keresetek benyújtásakor.

- Etnikai, nyelvi hovatartozásról való nyilatkozattétel: Dél-Tirolban mindenkitől megkövetelik, hogy az esedékes országos népszámláláskor hivatalos nyilatkozatot tegyen, hogy melyik etnikai csoporthoz (német, olasz, ladin) tartozik.

- Etnikai arányosság elve: az arányosság elve vonatkozik minden állami és félállami hivatalra. Ennek következtében számos állás, foglakozás betöltésénél fontos elvárás továbbra is a nyelvvizsga (Sipos 1993: 54-66.).

\section{Dél-Tirol jelene és jövője}

\section{Etnikai kérdés}

Az autonómia-megállapodás értelmében Dél-Tirolban három nyelvet ismernek el hivatalosan: a németet, az olaszt és a ladint. A tartomány etnikailag tagolt, és a három kisebbség egymás mellett élése sem zökkenőmentes. Sajnos Dél-Tirol esetében az etnikai „,szétválasztás” és megkülönböztetés a mindennapokban is érvényesül. Az alábbiakban erre szeretnék néhány konkrét példát hozni.

A nyelvi-etnikai szembenállás megjelenik a tartományi intézmények, az oktatás, a média területétől kezdve egészen a civil szervezetek etnikai alapon történő megkülönböztetéséig. Az oktatási rendszer teljesen megosztott az óvodától egészen a felsőoktatásig. A különböző nemzetiségü iskolákban anyanyelven folyik az oktatás, anyanyelvü tanárokkal. Ha például egy olasz és német iskola éppen egy épületben müködik, akkor korlátozzák a tanulók és oktatók közötti érintkezéseket, de arra is volt már precedens, hogy az órák közötti szüneteket is eltérő időpontokban határozták meg. A németek továbbra is elutasítják a kéttannyelvủ iskolák bevezetését, félve attól, hogy a szülők inkább azt választanák gyermekeik számára a későbbi karrierlehetőségek miatt (Gulyás 2007: 76-82.). Számos kulturális szervezet, egyesület, könyvtár is etnikai alapon müködik. Az etnikai megosztottság a helyi médiában is érvényesül. Az elektronikus és a nyomtatott médiának is van egy német és olasz megfelelöje, így a német ajkúak helyi lapja a Der Dolomiten is leginkább csak a német eseményekről számol be. A tudósítások is nemzetiségi alapon működnek, de például a ladinok (a legkisebb népcsoport) naponta csak öt percben sugározhatnak müsort anyanyelvükön. Érdekességképpen említem meg, hogy mentőszolgálatból, de még hegymászó szövetségből is kettő van, természetesen egy olasz (Club Alpino) és egy német (Alpenverein Südtirol) (Pallaver 2007: 313-324.).

\section{Politikai kérdés}

A régióban felerősödő radikális nézetek mögött, egy „többszereplős” folyamat húzódik meg. Tény, hogy az autonómiastátusz biztosította az egyes etnikumok, németek, olaszok, ladinok békés egymás mellett élését, de a mesterségesen megkonstruált tartomány, a korábbi eröszakos olaszosítás és az eurózóna válsága miatt felerősödő regionális ellentétek mindinkább kihatnak a régió mindennapjaira.

Az etnikai tagoltság jól kimutatható Dél-Tirol politikai intézményrendszerén is. A korábban szinte minden helyi/regionális választás nyertese az SVP, a legutolsó 2008-as választásokon nem került abszolút többségbe. A 2008-as tartományi választásokon 15 párt indult, melyek közül 6 német, 8 olasz és 1 ladin szervezet képviseltette magát. A választásokat 2008-ban ismét a Dél-Tiroli Néppárt (SVP) nyerte meg, amely 146.545 voksot kapott az összesen leadott 304.615 szavazatból, ezzel a tartományi gyülésben betölthető helyek 48,1\%-át szerezte meg.

Bár a 2008-as választásokat ismét a Dél-Tiroli Néppárt (SVP) nyerte, a 35 képviselöi helyből csak 18-at sikerült megszereznie. A Néppárt ezért arra kényszerült, hogy olasz pártokkal lépjen szövetségre. Ez a „kényszerhelyzet” természetesen még inkább felerősítette a kisebb német pártok ellenérzéseit. Dél-Tirolban a 2008-as választási eredmények és az országban súlyosbodó gazdasági válság hatására a német ajkú ellenzéki pártok (Szabadelvűek, Dél-Tiroli Szabadságpárt, Unió DélTirolért) igen kemény kritikát fogalmaztak meg az olasz nemzetállammal szemben. Sokan a térség jövőjét illetően a „Rómától való elszakadást”,

\footnotetext{
${ }^{5}$ http://www.provincia.bz.it/vote/landtag2008/info/partiti_li_vg.htm.
} 
vagy egy nagyobb fokú autonómia biztosítását látják elképzelhetőnek (Klotz, 2011.).

Az ellenzéki pártok hangsúlyozzák, hogy jövőjüket egy Dél-Tiroli Szabadállamban vagy az Ausztriához való visszatérésben látják megoldhatónak. Az olasz nemzeti identitásnak ők nem részesei, és nem is lesznek soha. ${ }^{6}$

A jelenlegi helyzetben fokozatosan emelkedik a radikális, szeparatista csoportok társadalmi támogatottsága. Számos vezető politikus nyilatkozott úgy, hogy Róma követeléseinek nem hajlandóak eleget tenni. Thomas Widmann, dél-tiroli gazdasági miniszter, a konzervatív Dél-Tiroli Néppárttal együtt azt javasolta, hogy Dél-Tirol vásárolja meg függetlenségét Olaszországtól. Wildmann szerint Olaszország teljes tartozása 1911 billiárd euró. Tekintettel arra, hogy Dél-Tirolban ötszázezren laknak, ez arányosítva nekik összesen 15 milliárd eurót jelent, így amennyiben DélTirol kifizetné ezt az összeget Rómának, akkor teljes autonómiát kaphatna (Sachelli, 2011).

A közvélemény-kutatások szerint a szeparatista mozgalmak egyre nagyobb mértékben vonzzák a fiatalokat. Günther Pallaver, dél-tiroli politikus szerint általánosnak mondható tendencia, hogy a tartomány politikailag egyre jobbra tolódik. Az egykori legnagyobb gyüjtőpárt, az SVP fokozatosan veszít népszerüségéből, a kisebb radikális helyi pártok pedig növelik támogatottságukat. Míg az 1970-es években a fiatalok 90\%a egyetértett a korlátozott autonómiával, addig mára ez az arány $60 \%$-ra csökkent (Pallaver 2000: 313-324.).

\section{Gazdasági kérdés}

Dél-Tirol gazdasági mutatóit tekintve Olaszország leggazdagabb régiója. Az egy före jutó GDP kb. 30000 euró, ami majdnem kétszerese a szicíliai régióénak. ${ }^{7} \mathrm{~A}$ költségvetés tekintetében Dél-Tirol önfinanszírozó, tehát forrásainak $90 \%$-a a régióban befizetett adókból származik. A regionális önkormányzatiság megteremtése nagymértékben elősegítette a sikeres

http://www.corriere.it/unita-italia-150/11_marzo_10/de-cesare-italia-unita-fanalinocoda_13e7441c-4b22-11e0-9e9a-b429a0ac9415.shtml.

${ }^{7}$ http://www.ilgiornale.it/news/lega-attacca-noi-non-festeggiamo-lunit-nuovi-boicottaggie.html. gazdaságpolitikát a térségben. A hatásköröknek és a befolyt adóknak az állam és a regionális önkormányzat közötti megosztása segítette a gazdasági fejlödést. Ennek köszönhetően ma a régióban $2 \%$ alatti a munkanélküliség, és ennek következtében majdnem teljes a foglalkoztatottság (Tronconi, 2009).

A döntéshozatal regionális szintre történő leszállítása, a szubszidiaritás elvének alkalmazása növelte a térség politikai és gazdasági müködőképességét. A dél-tiroli autonómiának a regionális gazdasági, szociális és környezetvédelmi politikában elsősorban három eszköz áll rendelkezésére: a területfejlesztés, a térség iparának és kereskedelmének ösztönzése, valamint a költségvetési politika. A sikeres autonómiamodell megalkotása mellett azonban szembesülni kellett azzal a politikai jelenséggel, amely számos más európai országban is kulcsfontosságú kérdéssé vált. Elsősorban azokban az országokban, ahol jelentős etnikai csoport él egy koncentrált helyen, régióban (Spanyolország, Belgium stb.) Róma a régiótól 120 millió euró támogatást szeretne, hogy ezzel az olasz költségvetési mérleg egyensúlyba kerüljön. Ezzel a döntéssel viszont a római vezetés éppen azokat az észak-olasz régiókat sújthatja szankciókkal (Dél-Tirol, Lombardia, Piemont), melyek már így is a legnagyobb befizetők a központi államkasszába. A konfliktus tehát Dél-Tirol és Róma között kicsiben is tükrözi az egész euróválságot: a „gazdag Észak” nem kívánja tovább támogatni és eltartani a „szegény Délt”. Ennek hatására mind Olaszországban, mind a régióban a korábbi törésvonalak tovább mélyültek, ami felszínre hozta a radikális, jobboldali szervezetek fokozatos térnyerését, kérdésessé téve a politikai erőviszonyok átrendeződését a térségben.

\section{Konklúzió}

Összegzésként megállapítható, hogy Dél-Tirol esetében a radikális mozgalmak megerősödése, intézményesülése és növekvő támogatottsága mögött több tényező együttes hatása húzódik meg. A hosszú diplomáciai egyeztetések során megszületett autonómiamodell sem jelenthet teljes garanciát arra, hogy a régióban az etnikai jellegü konfliktusok végleg eltünnek. A térség kimagasló gazdasági mutatói, szemben Olaszország többi régiójával, és a német ajkúak erős identitástudata együttesen eredményez- 
te azt, hogy a régión belül a jobboldali radikális formációk száma és ezek támogatottsága az elmúlt években jelentősen megnövekedett, ezáltal a déltiroli függetlenségi és szeparatista törekvések megoldása és kezelése ismét az olasz belpolitika egyik legégetőbb problémájává vált.

\section{Hivatkozott irodalom}

1861. L'Italia unita fanalino di coda rispetto all'Europa. Interneten: http://www.corriere.it/unita-italia-150/11_marzo_10/de-cesare-italiaunita-fanalino-coda_13e7441c-4b22-11e0-9e9ab429a0ac9415.shtml, letöltve: 2012. 04. 02.

A dél-tiroli választási oldal. Internet: http://www.provinz.bz.it/en/downloads/South-Tyrol-Autonomy.pdf, letöltve: 2012.03. 20.

Floris, GiovanNi (2009): Separati in Patria. Nord contro Sud:perché l'Italia é sempre piú divisa. Milano, Rizzoli.

GULYÁS LÁSZLÓ (2007): A kisebbségi kérdés megoldásának egy pozitív példája: Dél- Tirol esete II. Korunk 18 (1),76-82.

Kotz, Eva (2011): Mio papà, il martellatore della Val Passiria» Dopo 50 anni l'altra verità. Internet:

http://www.stefanolorenzetto.it/pagine/interviste/Klotz.pdf, letöltve: 2012.04. 02.

MikLÓSNÉ ZAKAR ANDREA (2010): Autonómia-elmélet és gyakorlat. Tér és Társadalom 24 (3),75-91.

NAGY IstVÁN (2009): Autonómia - az olasz példa. Nemzet és Biztonság 2 (1), 28-35.

ORMOS MÁRIA-MAJOROS ISTVÁN (1998): Európa a nemzetközi küzdötéren. Budapest, Osiris.

PALLAVER, GÜNTHER (2000): Dél-Tirol: multikulturális tartomány? Ford.: Veledits Felicitász. Educatio 9 (2), 313 -324.

PALlaVER, GÜNTHER- FerRANDI, GIUSEPPE (2007): La Regione TrentinoAlto Adige/Südtirol nel XX secolo.. Trento, Politica e istituzioni, Fondazione Museo Storico del Trentino.

Sacchelli, Orlando (2011): La Lega attacca: "Noi non festeggiamo l'Unità" Nuovi boicottaggi. E riesplode la polemica... Internet: http://www.ilgiornale.it/news/lega-attacca-noi-non-festeggiamolunit-nuovi-boicottaggi-e.html, letöltve: 2012. 03. 08.

SCHÖNBAUM ATTILA (2008): Nemzeti és etnikai kisebbségek parlamenti képviselete Európában - Egy dolgozat hipotézisei. Kisebbségkutatás 17 (1), $7-26$.

SiPOS KATALIN (1993): A nyelvi kisebbségek védelme Olaszországban. Régió 4 (1), 54-66.

SzOMRÁKY BélA-RAJNAVÖLGYI GÉZA (1999): Pan, Christoph: Tartomány a határon. Beszélgetés Christoph Pan professzorral. Európai utas 37 (1), 7-11.

TRONCONI, FILIPPO (2009): I partiti etnoregionalisti: La politica dell'identità territoriale in Europa occidentale. Collana "Il Mulino/Ricerca", Milano. 